УДК 629.083

DOI: https://doi.org/10.26642/ten-2020-2(86)-3-12

\author{
С.I. Андрусенко, к.т.н., проф. \\ О.С. Бугайчук, к.т.н., доц. \\ А.В. Лобода, к.т.н., доц. \\ Д.О. Савостін-Косяк, к.т.н. \\ Національний транспортний університет
}

\title{
Оцінка вартостей експлуатації транспортних засобів з різними типами силових установок
}

\begin{abstract}
У статті представлено методику розрахунку вартості експлуатацї автомобілів з різними видами силових установок. Визначено вихідні дані й проведено розрахунки елементів собівартості експлуатації автомобілів з бензиновими, гібридними силовими установками та електромобілів. Показано, щчо дочільність використання різних типів автомобілів залежить від вартості самого автомобіля та вартостей таких різних компонентів експлуатації, як пальне, електроенергія, робоча сила, експлуатаційні матеріали, особливості податкового законодавства тощуо, і має визначатися відповідно до умов кожної краӥни. У багатьох випадках сукупна вартість використання електромобілів $\epsilon$ більшою, ніж транспортних засобів 3 двигунами внутрішнього згоряння та гібридів. Якщуо не враховувати вартість автомобіля $i$ пов 'язані з нею амортизаційні витрати, то експлуатація електромобілів є у 3-5 разів дешевшою за експлуатацію гібридів, $і$ в 5-8 разів дешевшою за експлуатацію автомобілів з ДВЗ.

Подальші дослідження варто спрямувати на розширення кількості факторів, які будуть більш детально враховувати умови експлуатації транспортного засобу. Також варто продовжувати роботу над розвитком бази даних результатів розрахунку з метою виявлення найбільш економічно доцільних транспортних засобів для різних умов експлуатації.
\end{abstract}

Ключові слова: автомобіль з двигуном внутрішнього згоряння; гібрид; електромобіль; собівартість експлуатації; порівняльний аналіз.

Актуальність теми. На теперішній час на ринку легкових автомобілів разом 3 традиційними автомобілями 3 двигунами внутрішнього згоряння (ДВ3) на рідкому або газовому паливі збільшується пропозиція автомобілів з гібридними силовими установками та автомобілів на повністю електричній тязі.

Транспортні засоби (Т3), які використовують електроенергію для руху, можна класифікувати таким чином:

- електромобіль (BEV) - автомобіль, що рухається від одного або декількох електродвигунів 3 живленням від акумулятора;

- гібрид (HEV) - автомобіль, що використовує для руху комбінацію ДВ3 і електродвигуна. У гібридах використовують три схеми використання потужностей ДВЗ та електродвигуна: послідовну, паралельну та послідовно-паралельну. Електродвигун живиться від акумулятора, який заряджається від ДВЗ;

- $\quad$ плагін-гібрид (PHEV) - гібридний автомобіль, акумулятор якого може підзаряджатися від мережі електричного струму. Він $є$ проміжною конструкцією між гібридом і електромобілем. Такі ТЗ у цьому дослідженні не розглядалися. У плагін-гібридів більш потужні електромотори та акумулятори більшої ємності. Запас ходу на чистій електротязі у PHEV більший, ніж у HEV і досягає 100 км.

Загальна кількість легкових транспортних засобів на електричній тязі (електромобілі, гібриди та плагін-гібриди) на листопад 2019 року в Україні становила 34029 одиниць [1]. Серед них 17710 електромобілів та 16319 гібридів і плагін-гібридів. Це - 2,7\% та 2,47\% відповідно від загальної кількості транспортних засобів для перевезення людей.

На кінець 2019 року [1] автомобілі марки «Nissan» становили $39 \%$ від загальної кількості зареєстрованих електромобілів в Україні (рис. 1). Серед гібридних автомобілів більшу частину ринку (44 \%) займають транспортні засоби марки «Тоуота» (рис. 2).

Варто зазначити, що кількість автомобілів на електричній тязі в Україні щорічно подвоюється, проте 90 \% 3 них - це автомобілі з пробігом [2]. Така тенденція пояснюється тим, що в Україні скасовано імпортні мита та необхідність сплачувати ПДВ для цього сегмента автомобілів [3]. Іншим важливим фактором є питомі витрати на енергоресурси, які необхідні для подолання одного кілометра шляху. В дослідженні [4] показано, що витрати на енергоресурси для автомобілів з ДВ3 вищі в 2-8 разів. Проте у цьому дослідженні враховується лише вартість енергоносія, в той час як повна вартість експлуатації містить у собі більшу кількість складових, які варто розглянути детальніше. 

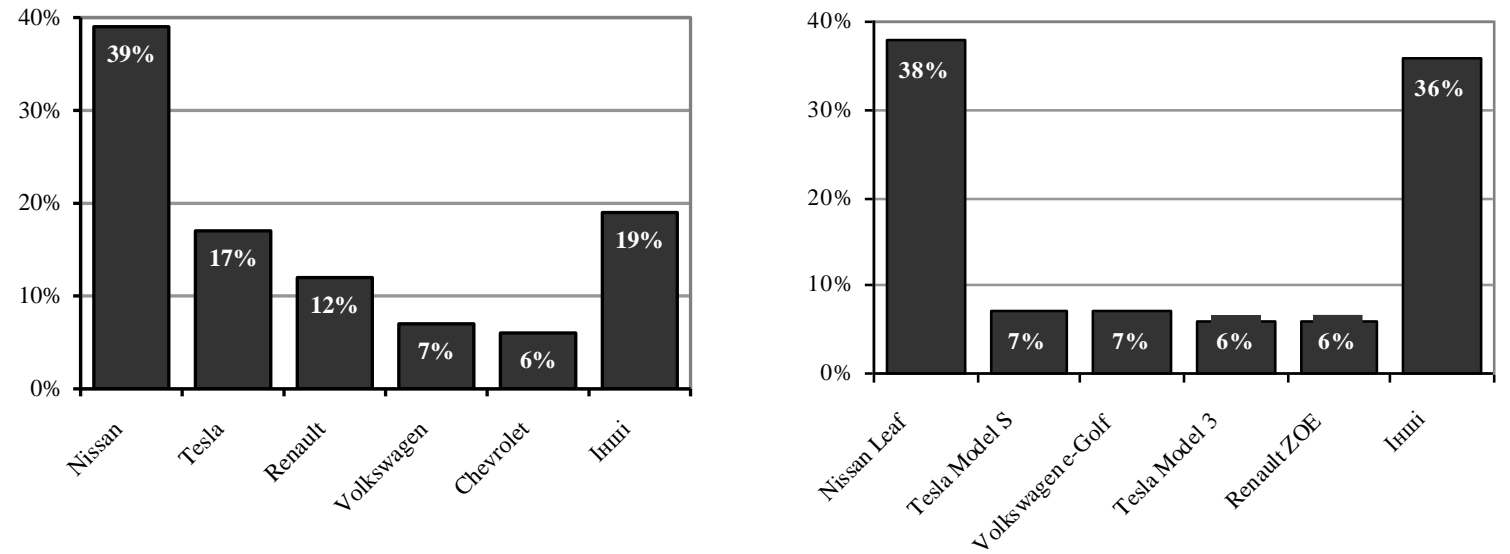

Рис. 1. Розподіл електромобілів за марками та моделями в Україні на кінецьь 2019 року
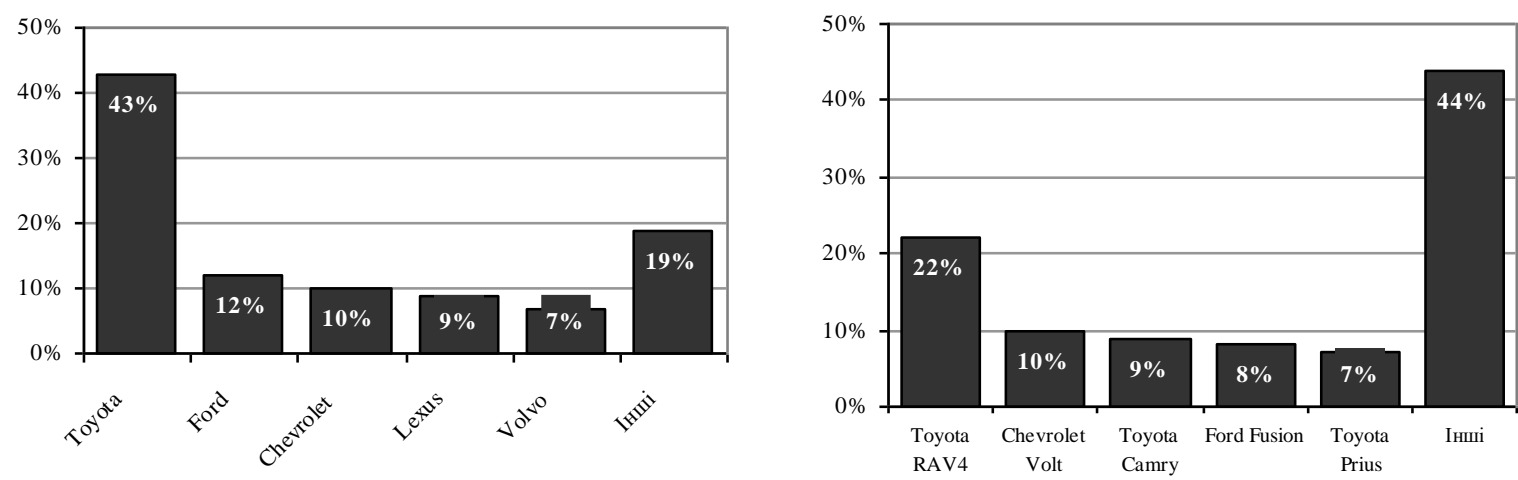

Рис. 2. Розподіл гібридів за марками та моделями в Украӥні на кінецьь 2019 року

Аналіз останніх досліджень та публікацій свідчить, що питанням оцінки вартості експлуатації автомобілів з різними типами силових установок займалося багато авторів. У $[5,6]$ визначалася вартість експлуатації та ремонту електромобіля «Nissan Leaf» в Україні. В них показано, що при експлуатації, обслуговуванні та ремонті відповідно до рекомендацій заводу-виробника, цей транспортний засіб, порівняно з традиційними ДВЗ-автомобілями, є більш надійним та дешевим у використанні. Проте в цих дослідженнях враховувалася вартість обслуговування на незалежних автосервісних підприємствах.

У [7] розглянуто експлуатаційні показники електромобілів та оцінено доцільність їх експлуатації в міських умовах. Зазначено, що вартість проїзду ста кілометрів у місті на бензиновому легковому автомобілі в середньому дорівнює 200 грн, а на електромобілі - 8-12 грн. Зроблено висновок, що електромобіль економічно доцільно використовувати в умовах міста за високої інтенсивності експлуатації - більше 50 км пробігу на добу [7]. Проте у цій статті не деталізовано категорії експлуатаційних витрат та їх частка в загальній вартості.

Стаття [8] присвячена аналізу досвіду експлуатації електромобілів у Німеччині. Розглянуто такі різні аспекти, пов'язані з використанням електромобілів, як економічні, екологічні, зручність використання. Наведено детальний розрахунок витрат на енергоносії, технічне обслуговування, враховано податки, які стягуються з власників транспортних засобів на території Німеччини, зроблено висновок, що у деяких випадках використання електромобілів є дорожчим та менш зручним. Однак під час розрахунків автор не враховує низку факторів, наприклад витрати на шини та амортизацію транспортного засобу.

Німецький автомобільний клуб (ADAC) опублікував дослідження, яке присвячене вартості експлуатації електромобілів порівняно з бензиновими і дизельними аналогами [9]. Дослідження показало, що автомобілі з ДВЗ здебільшого є дорожчими в експлуатації. Вартість 1 км пробігу автомобіля BMW i3 дорівнює 53,6 євроцента, а для бензинового BMW 218i Active Tourer цей показник становить 60,6 євроцента. У випадку дизельного ВMW 218d вартість 1 км пробігу знижується до 57,4 євроцента, що все одно вище, ніж в електричній версії i3. Hyundai Ioniq Electric долає 1 км за 49 центів, а бензиновий i30 - за 51,4; дизельний потребує 52 євроценти. Renault Zoe витрачає на 1 км 
свого пробігу 48 центів, тоді як бензиновий Renault Clio обходиться дешевше - 36,4 євроцента. Результати дослідження на прикладі інших автомобілів виявилися ще більше неоднозначними: Smart Fortwo Coupe EQ/ бензиновий Fortwo: 36,9/38,7 євроцента; VW e-Up / бензиновий VW Up: 39,1 / 34,0 євроцента; VW e-Golf / бензиновий 1.5TSI / дизельний 1.6 TDI: 48,6 / 49,0 / 47,0 євроцента; Tesla Model X 100D/дизельна Audi SQ7 TDI: 131,9/137,7 євроцента. Це дослідження враховує особливості законодавства Європейського Союзу. В Україні діють інші нормативно-правові акти, податкове законодавство та ціни на енергоносії і тому результати розрахунків можуть суттєво різнитися.

Аналогічні дослідження були проведені Інститутом транспортних досліджень в Мічигані (Michigan Transportation Research Institute) для автомобілів, що експлуатуються в Америці [10]. У цьому дослідженні враховувалася лише вартість енергоресурсів і не враховувалася вартість технічного обслуговування, витрати на шини та амортизацію транспортного засобу, а якраз амортизаційні відрахування можуть становити значну частину експлуатаційних витрат. Цей фактор особливо важливий для автомобілів, які знаходяться у комерційній експлуатації або службовому користуванні.

Порівняння повної вартості експлуатації двох автомобілів марки «Renault»: електромобіля та дизельного аналога, з урахуванням первинної вартості, амортизаційних відрахувань, вартості технічного обслуговування та витрат на енергоносії, наведено в роботі [11]. Результати дослідження показали, що економічно більш доцільно експлуатувати автомобіль 3 дизельним двигуном, але цей ефект досягається лише за рахунок значно нижчої первинної вартості і, як наслідок, менших амортизаційних відрахувань. У цьому дослідженні не враховувалися витрати на шини та поточний ремонт. Також варто зазначити, що в основу цих досліджень було покладено параметри, які автори вважали за необхідне врахувати з огляду на власний досвід, хоча доцільно було б взяти за основу чинні в Україні нормативні документи.

У [12] описано деякі складові витрати на експлуатацію електромобіля та автомобіля з бензиновим ДВ3, наведено регламентні роботи щодо технічного обслуговування і їх вартості, здійснено порівняння вартостей експлуатації електромобілів та автомобілів з ДВЗ. Враховувалися лише витрати на паливо та електроенергію, а також вартість регламентного технічного обслуговування без урахування витратних матеріалів. Показано, що в Україні витрати на експлуатацію електромобіля «Nissan Leaf» значно менші, ніж витрати автомобіля «Nissan Tiida», за рахунок меншої вартості регламентного технічного обслуговування та електроенергії порівняно з вартістю бензину.

Таким чином, зважаючи на результати аналізу останніх досліджень, можна побачити, що в більшості випадків враховується вартість енергоресурсів та технічного обслуговування і не враховується вартість поточного ремонту, витрати на шини та амортизаційні відрахування, хоча ці складові $\epsilon$ частиною експлуатаційних витрат. Крім того, на цей момент відсутня універсальна методика оцінки собівартості експлуатації транспортних засобів з різними типами силових установок.

Метою статті $\epsilon$ розробка методики визначення собівартості експлуатації транспортних засобів 3 різними типами силових установок на базі нормативних документів, що діють в Україні, та порівняння вартості використання таких транспортних засобів.

Викладення основного матеріалу. Собівартість експлуатації (CE) дорожніх транспортних засобів (ДТЗ) при економічних розрахунках визначається відповідно до вимог Положення (стандарту) бухгалтерського обліку 16 «Витрати» [13]. Для забезпечення можливості порівняння різних ДТЗ розраховується питома собівартість експлуатації (ПСЕ) як відношення собівартості експлуатації до виконаної транспортної роботи (ТР) у машино-кілометрах за певний період часу. Повна собівартість експлуатації ДТЗ містить виробничу собівартість, адміністративні витрати, витрати на збут, інші витрати операційної діяльності. Вплив конструктивних властивостей ДТЗ на собівартість експлуатації відображає виробнича собівартість.

Виробнича собівартість складається 3 матеріальних та інших прямих витрат на експлуатацію транспортного засобу, які містять витрати на паливо, мастильні матеріали, шини, акумуляторні батареї, витрати на електроенергію, що споживається на тягу рухомого складу, витрати на амортизацію ДТЗ, основних засобів та нематеріальних активів виробничого призначення, витрати на всі види ремонту, запчастини, технічний огляд і технічне обслуговування ДТЗ $[14,15]$.

Суттєвими факторами, що визначають вартість експлуатації автомобіля, за умови інших незмінних або майже однакових для різних типів ДТЗ, можуть бути такі, що показані нижче у рівнянні для розрахунку собівартості експлуатації транспортних засобів на 1 км пробігу:

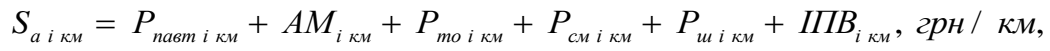

де $P_{\text {павт і км }}$ - питомі витрати на паливо або електроенергію на рух для автомобіля, грн/км;

$A M_{\text {км }}$ - амортизація автомобіля (та певних складових інфраструктури, наприклад, зарядної станції у разі необхідності ії придбання), грн/км;

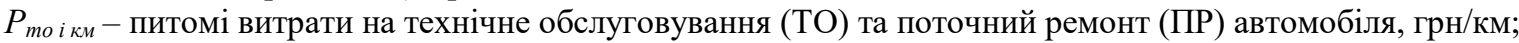

$P_{c м і к м}-$ питомі витрати на мастильні та експлуатаційні матеріали для автомобіля, грн/км;

$P_{\text {ш } і к м}-$ питомі витрати на зношування та ремонт шин, грн/км;

$I П B_{\text {ккм }}-$ інші прямі витрати (наприклад, податок на ДТЗ, страхування тощо), грн/км;

$i$ - вид ДТЗ. 
Питомі витрати на паливо можуть бути визначені за:

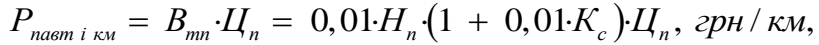

де $B_{m n}$ - загальна нормативна витрата палива на 1 км пробігу за конкретних умов експлуатації, л/км $\left(\mathrm{M}^{3} / \mathrm{Kм}\right)$;

$H_{n}$ - базова лінійна норма витрат палива для конкретної марки транспортного засобу, л/100 км (м³/100 км);

$K_{c}$ - сумарний коригуючий коефіцієнт базової лінійної норми $H_{n}$, яким враховуються конкретні умови експлуатації;

$Ц_{n}$ - прогнозована ціна палива, грн/л (грн/м³).

Для розрахунків можуть бути використані дані виробників автомобілів для міського циклу без коригування [16].

Вартість спожитої електромобілем на рух електроенергії визначається за:

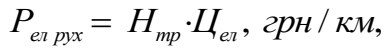

де $H_{m p}$ - питома витрата електроенергії на рух автомобіля, кВт-год/км;

$Ц_{е л}-$ ціна електроенергії, грн/кВт-год.

Питому витрату електроенергії на рух можна визначити за:

$$
H_{m p}=\frac{\epsilon_{A K Б}}{L}, \kappa B m-20 \partial / \kappa M,
$$

де $\epsilon_{A K Б}$ - заряджена в тягову АКБ і сплачена кількість електроенергії, кВт-год;

$L-$ пробіг автомобіля на одній зарядці.

$H_{m p}$ може бути визначена як відношення заявленої виробником ємності тягової акумуляторної батареї (АКБ) до пробігу на одній зарядці.

Ціна електроенергії залежить від умов зарядження. Найбільш поширеними способами зарядження електромобілів є:

- зарядні станції на платних стоянках, стоянках бізнес- та торговельних центрів;

- мережеві зарядні станції (аналоги мережевих автозаправних станцій);

- домашні зарядні станції, які працюють від 380 Вт;

- $\quad$ домашні зарядні пристрої, що працюють від 220 Вт [4].

Найбільш дешевим та зручним є зарядження батареї в домашніх умовах вночі за багатотарифного обліку. Проте домашня зарядна установка на 3,7 кВт коштує від 750 євро, а на 7,2 кВт - від 900 євро. При використанні двофазної мережі електропостачання 220 вольт з максимальним током 16 ампер досягається потужність 3,52 кВт. 3 міркувань безпеки можна використати не більше 2,5 кВт потужності у побутових умовах. Тобто для повного заряджання батареї «Nissan Leaf» 3 акумулятором 24 кВТ-год необхідно 9,6 год, а для батареї 40 кВт-год - 16 год. Автомобілю «Tesla Model S» 3 батареєю 100 кВт-год для повної зарядки необхідно 40 год. За використання трьохфазної мережі 380 вольт і струму 16 ампер може бути використано з урахуванням $\cos \varphi$ приблизно 7,3 кВт. Тоді час зарядки для «Nissan Leaf» зменшиться до 3,3-5,5 год, а для «Tesla Model S»- до 14 год. При цьому, наприклад для м. Києва, вартість електроенергії за споживання більше 100 кВт-год/місяць становить за однотарифного обліку 1,68 грн/кВтгод, а за двозонного тарифу нічна вартість електроенергії з 23:00 до 7:00 дорівнює 0,84 грн/кВт-год.

Питомі витрати на амортизацію ДТЗ розраховуються за:

$$
A_{T 3}=\frac{A_{T 3 \text { рiч }}}{L_{p i \varphi}}, \text { грн } / \kappa м,
$$

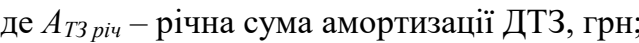

$L_{\text {річ }}$ - річний пробіг ДТЗ, км;

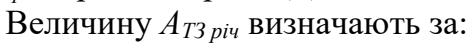

$$
A_{p i 4}=\frac{C_{T 3}}{T_{\text {вик }}}, \text { грн, }
$$

де $C_{T 3}$ - первісна або переоцінена вартість Т3 за вирахуванням ліквідаційної вартості ДТЗ;

$T_{\text {вик }}$ - термін корисного використання ДТЗ, років.

Питомі витрати на технічне обслуговування (ТО) автомобіля та вартість експлуатаційних матеріалів визначаються за:

$$
P_{\text {то і км }}=\frac{\Sigma T_{i} \cdot B_{\text {нг }}}{L}+\Sigma B_{\text {ем, },}, \text { грн } / \kappa м,
$$

де $\Sigma T_{i}$ - сумарна трудомісткість ТО автомобіля за пробіг L, нормо-годин;

$B_{\text {нг }}$ - вартість нормо-години з ПДВ, грн;

$L-$ пробіг автомобіля, км;

$\Sigma B_{\text {eм,i }}$ - сумарна вартість експлуатаційних матеріалів та складових, що використовуються за все ТО при пробігу $L$, грн.

Питомі витрати на шини для автомобіля розраховуємо за [14]: 


$$
P_{u i}=\frac{n_{u i} \cdot C_{u i}}{1000 \cdot H_{i}}, \text { грн/км, }
$$

де $n_{u i}-$ кількість шин, встановлених на автомобілі, од.;

$C_{u i}$ - середня ринкова вартість однієї шини, грн [17];

$H_{i}$ - норма експлуатаційного пробігу однієї шини, тис. км.

Для порівняння було обрано найбільш розповсюджених в Україні представників кожної 3 груп транспортних засобів згідно 3 [1, 2], а саме: «Nissan Juke», «Nissan Leaf», «Toyota RAV 4 2.5i», «Toyota RAV 4 2,5 Hybrid», «Toyota Prius» та «Tesla Model S».

Також при розрахунках було прийнято низку припущень:

- автомобілі заряджалися в домашніх умовах від зарядного пристрою за нічним тарифом при двотарифному обліку [4];

- автомобілі за сім років експлуатації втратять 50 \% первісної вартості;

- технічне обслуговування проводиться на офіційних дилерських станціях;

- витрати на поточний ремонт дорівнюють нулю;

- інші можливі прямі витрати (наприклад, податок на ДТ3, страхування тощо) дорівнюють нулю;

- всі автомобілі експлуатуються в однакових умовах міського циклу.

Інформацію щодо вартості автомобілів було взято згідно з $[16,18]$, регламенти та вартості технічного обслуговування для «Nissan Juke» та «Nissan Leaf» - згідно з [19], для «Toyota Prius», «Toyota RAV 4 2.5i» та «Toyota RAV 4 2,5 Hybrid» - згідно з [20, 21], для «Tesla Model S» - згідно з [22-24].

Характеристики автомобілів та параметри, необхідні для розрахунків їх питомої собівартості експлуатації, а також результати розрахунку наведені в таблиці 1.

Таблиия 1

Калькуляція питомих прямих витрат на експлуатацію різних типів транспортних засобів

\begin{tabular}{|c|c|c|c|c|c|c|}
\hline \multirow[b]{2}{*}{ Вихідні дані для розрахунку } & \multicolumn{6}{|c|}{ Транспортний засіб (ТЗ) } \\
\hline & $\begin{array}{l}\text { «Nissan } \\
\text { Juke» }\end{array}$ & $\begin{array}{c}\text { «Toyota } \\
\text { RAV } 4 \\
2.5 \mathrm{i} »\end{array}$ & $\begin{array}{l}\text { «Toyota } \\
\text { Prius» }\end{array}$ & $\begin{array}{c}\text { «Toyota } \\
\text { RAV } 4 \\
\text { Hybrid } \\
\text { 2,5» }\end{array}$ & $\begin{array}{l}\text { «Nissan } \\
\text { Leaf»» }\end{array}$ & $\begin{array}{c}\text { «Tesla } \\
\text { Model } \\
\mathbf{S} »\end{array}$ \\
\hline 1 & 2 & 3 & 4 & 5 & 6 & 7 \\
\hline $\begin{array}{c}\text { Первісна / переоцінена вартість } \\
\text { Т3, тис. доларів США }\end{array}$ & 15,7 & 24,2 & 31 & 31,614 & 33 & 87,7 \\
\hline $\begin{array}{c}\text { Первісна / переоцінена } \\
\text { вартість Т3, тис. грн }\end{array}$ & 392,5 & 605 & 775 & 790,35 & 825 & 2192,5 \\
\hline Коефіцієнт втрати вартості & 0,5 & 0,5 & 0,5 & 0,5 & 0,5 & 0,5 \\
\hline Залишкова вартість Т3, тис. грн & 196,25 & 302,5 & 387,5 & 395,175 & 412,5 & 1096,25 \\
\hline Термін використання, років & 7 & 7 & 7 & 7 & 7 & 7 \\
\hline Річний пробіг, тис. км & 15 & 15 & 15 & 15 & 15 & 15 \\
\hline Пробіг за 1 цикл зарядки, км & - & - & - & & 243 & 539 \\
\hline $\begin{array}{c}\text { Ємність тягової батареї, } \\
\text { кВт-год }\end{array}$ & - & - & - & & 40 & 100 \\
\hline $\begin{array}{c}\text { Витрати пального при міському } \\
\text { циклі, л/100 км }\end{array}$ & 7,7 & 9 & 3,1 & 4,8 & - & - \\
\hline $\begin{array}{c}\text { Витрати пального при } \\
\text { змішаному циклі, л/100 км }\end{array}$ & 6 & 7,8 & 3 & 4,7 & - & - \\
\hline $\begin{array}{c}\text { Вартість пального (бензин), } \\
\text { грн/л }\end{array}$ & 26 & 26 & 26 & 26 & - & - \\
\hline $\begin{array}{c}\text { Вартість електроенергії, } \\
\text { грн/кВт-год } \\
\end{array}$ & - & - & - & - & 0,84 & 0,84 \\
\hline $\begin{array}{c}\text { Пробіг за термін, } \\
\text { що розглядається, тис. км }\end{array}$ & 105 & 105 & 105 & 105 & 105 & 105 \\
\hline Вартість нормо-години, грн & 450,00 & 791,87 & 791,78 & 791,98 & 420,00 & 500,00 \\
\hline Трудомісткість ТО, нормо-год & 19,8 & 16,6 & 15,7 & 19,7 & 7 & 7 \\
\hline Вартість робіт ТО, грн & 8910,00 & 13145,00 & 12431,00 & 15602,00 & 2940,00 & 3500,00 \\
\hline
\end{tabular}




\begin{tabular}{|c|c|c|c|c|c|c|}
\hline \multicolumn{7}{|c|}{ Закінчення табл. 1} \\
\hline 1 & 2 & 3 & 4 & 5 & 6 & 7 \\
\hline Вартість ЗЧ та експл. мат., грн & 24925,00 & 17336,00 & 14828,00 & 16999,00 & 3632,00 & 4000,00 \\
\hline Сукупна вартість ТО, грн & 33835,00 & 30481,00 & 27259,00 & 32601,00 & 6572,00 & 7500,00 \\
\hline Кількість коліс на Т3 & 4 & 4 & 4 & 4 & 4 & 4 \\
\hline Марка шини & $\begin{array}{c}215 / 55 \mathrm{R} \\
17\end{array}$ & $\begin{array}{c}235 / 55 \mathrm{R} \\
18 \\
\end{array}$ & $\begin{array}{c}195 / 65 \mathrm{R} \\
15\end{array}$ & $235 / 55 \mathrm{R} 18$ & $\begin{array}{c}205 / 55 \mathrm{R} \\
16 \\
\end{array}$ & $\begin{array}{c}245 / 45 \\
\text { R19 }\end{array}$ \\
\hline Вартість однієї шини, грн & 1500 & 2753 & 1375 & 2753 & 2619 & 4491 \\
\hline Норма пробігу шини, тис. км & 70 & 70 & 70 & 70 & 70 & 70 \\
\hline Результати розрахунку & $\begin{array}{l}\text { «Nissan } \\
\text { Juke» }\end{array}$ & $\begin{array}{c}\text { «Toyota } \\
\text { RAV } 4 \\
2.5 \mathrm{i} »\end{array}$ & $\begin{array}{l}\text { «Toyota } \\
\text { Prius» }\end{array}$ & $\begin{array}{c}\text { «Toyota } \\
\text { RAV } 4 \\
\text { Hybrid } \\
\mathbf{2 , 5 »}\end{array}$ & $\begin{array}{l}\text { «Nissan } \\
\text { Leaf» }\end{array}$ & $\begin{array}{c}\text { «Tesla } \\
\text { Model } \\
\text { S» }\end{array}$ \\
\hline $\begin{array}{c}\text { Питомі витрати енергії на рух, } \\
\text { грн/км }\end{array}$ & 2,00 & 2,34 & 0,81 & 1,25 & 0,138 & 0,156 \\
\hline Питома вартість ТО, грн/км & 0,322 & 0,290 & 0,260 & 0,310 & 0,063 & 0,071 \\
\hline $\begin{array}{c}\text { Питома вартість зношування } \\
\text { шин, грн/км }\end{array}$ & 0,086 & 0,157 & 0,079 & 0,157 & 0,150 & 0,257 \\
\hline $\begin{array}{c}\text { Інші питомі прямі витрати, } \\
\text { тис. грн/км }\end{array}$ & 0 & 0 & 0 & 0 & 0 & 0 \\
\hline $\begin{array}{c}\text { Питомі витрати на амортизацію } \\
\text { авто, грн/км }\end{array}$ & 1,87 & 2,88 & 3,69 & 3,76 & 3,93 & 10,44 \\
\hline $\begin{array}{l}\text { Питомі витрати на } \\
\text { експлуатацію, грн/км }\end{array}$ & 4,28 & 5,67 & 4,83 & 5,48 & 4,28 & 10,92 \\
\hline $\begin{array}{l}\text { Витрати на експлуатацію } \\
\text { (без амортизації), грн/км }\end{array}$ & 2,41 & 2,79 & 1,14 & 1,72 & 0,35 & 0,48 \\
\hline
\end{tabular}

Результати розрахунків проілюстровані графіками на рисунках 3-6.

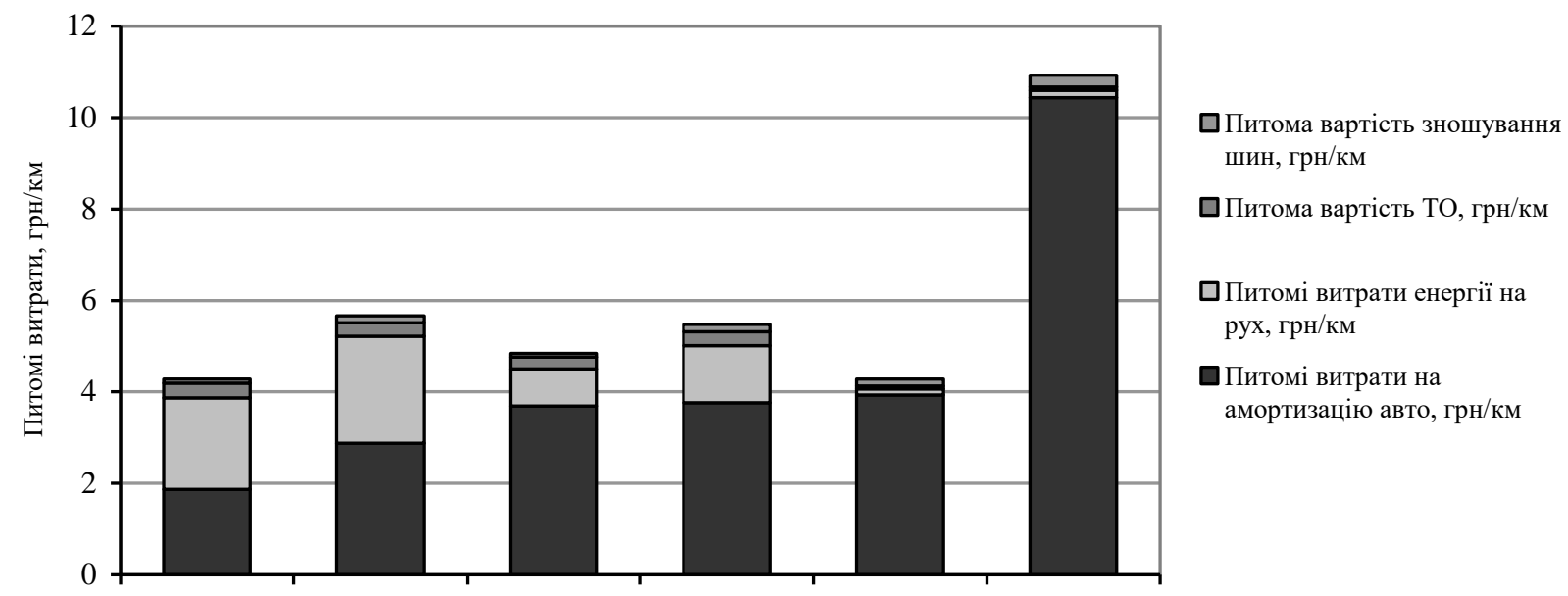

Nissan Juke Toyota RAV Toyota Prius Toyota RAV Nissan Leaf Tesla Model
$42.5 \mathrm{i}$
4 Hybrid 2,5
$\mathrm{S}$

Рис. 3. Сукупні питомі витрати на експлуатащฺію транспортних засобів, грн/км 


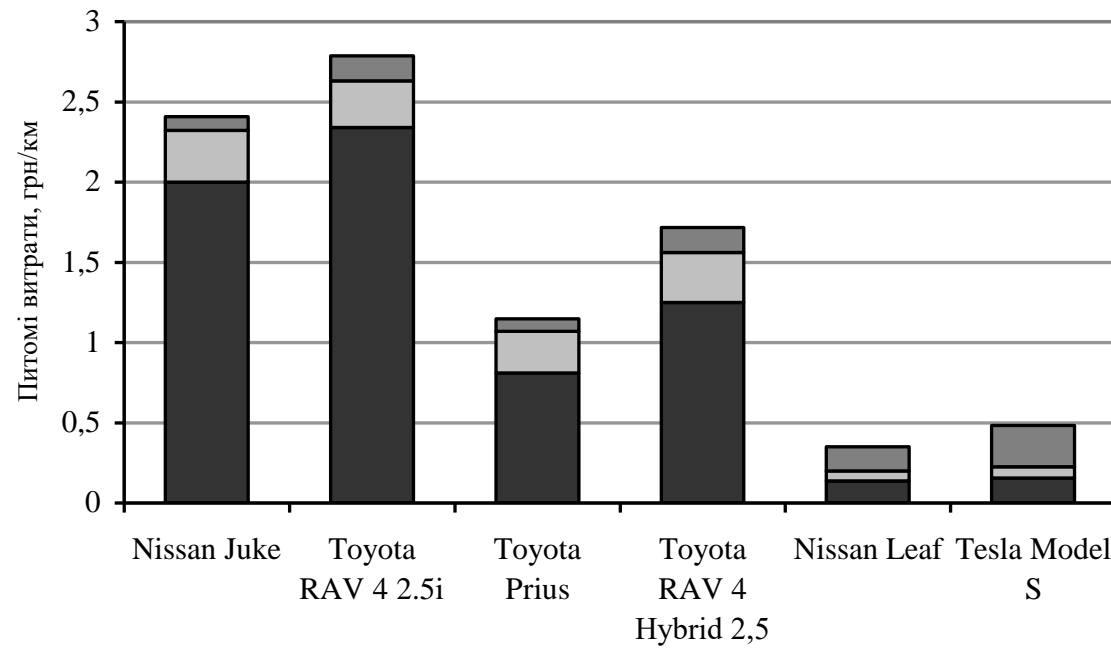

ППитома вартість зношування шин, грн/км

ППитома вартість ТО, грн/км

Питомі витрати енергії на рух, грн/км

Рис. 4. Питомі витрати на експлуатацію без урахування амортизації транспортних засобів, грн/км

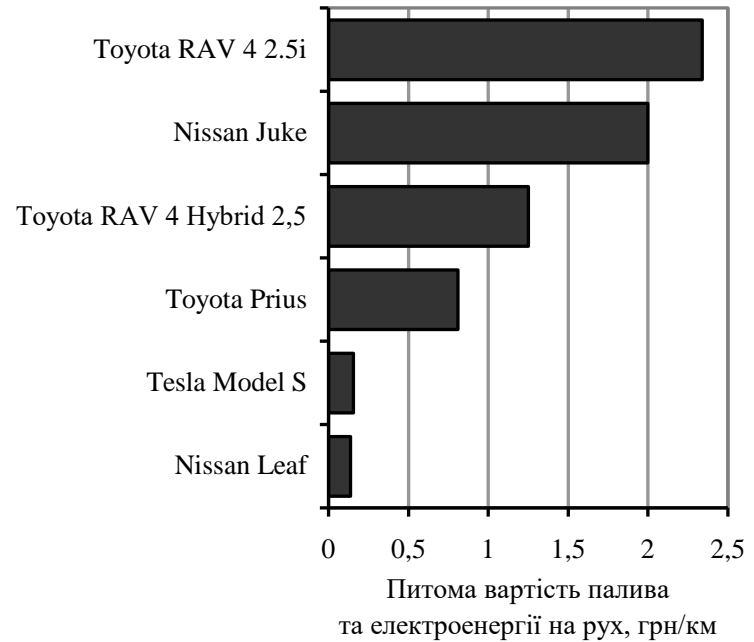

Рис. 5. Питома вартість палива та електроенергії на рух, грн/км

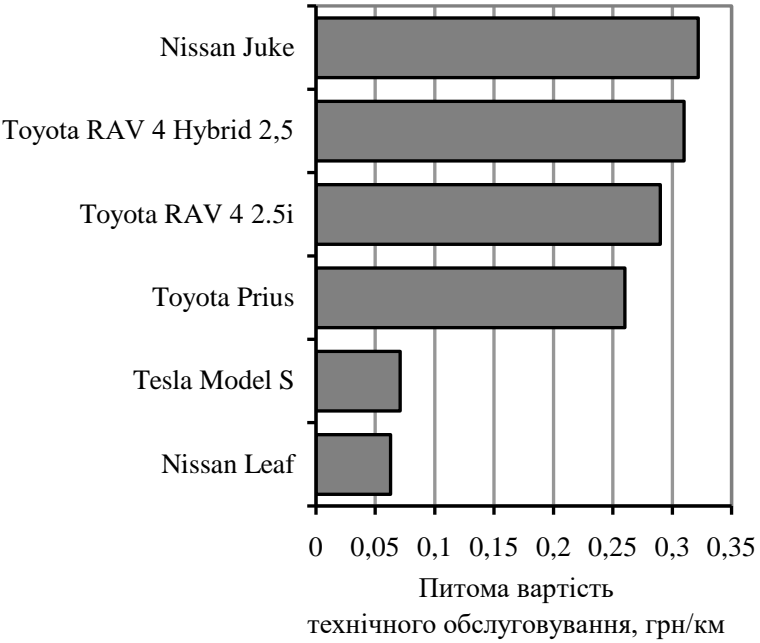

Рис. 6. Питома вартість технічного обслуговування, грн/км

За результатами розрахунків було встановлено, що найбільшу питому собівартість експлуатації мають автомобілі «Tesla Model S» (табл. 1, рис. 3) - 10,92 грн/км. Основною складовою таких витрат $є$ амортизаційні відрахування, які дорівнюють 10,44 грн/км, тобто 95,6 \% від загальної вартості експлуатації. Це зумовлено тим, що його первісна вартість майже утричі вища, ніж у решти транспортних засобів, що розглядаються. «Nissan Juke» та «Nissan Leaf» мають однакову питому собівартість експлуатації - 4,28 грн/км.

Питома собівартість експлуатації бензинового «Toyota RAV 4» на 3,47 \% вища, ніж для гібридної версії, та на 17,4 \%, ніж для «Тоуоta Prius». Найбільшу частку в питомій собівартості експлуатації електромобілів становлять витрати на амортизацію. Для «Nissan Leaf» цей показник складає 91,8\%, в той час як для гібридів він знаходиться на рівні 76,4 \% для «Toyota Prius» та 68,6 \% для «Тоуоta RAV 4 2,5 Hybrid». Найменшу частку амортизаційних відрахувань у питомій собівартості експлуатації мають автомобілі з бензиновим двигуном - 43,7 \% для «Nissan Juke» та 50,8 \% для «Toyota RAV $42.5 \mathrm{i} »$.

Без урахування амортизаційних відрахувань (рис. 4), питома собівартість експлуатації електромобілів $(0,35-0,48$ грн/км) у 3-5 разів нижча за питому собівартість експлуатації гібридів (1,14-1,72 грн/км) та в 5-8 разів нижча, ніж для автомобілів з ДВ3 (2,41-2,79 грн/км). Основними причинами такої різниці є значно менші витрати на енергоносії для приведення транспортного засобу в рух порівняно з витратами для гібридних та бензинових автомобілів (рис. 5).

Вартість технічного обслуговування електромобіля (рис. 6) у 4-5 разів менша, ніж у гібридів та бензинових автомобілів. Це зумовлено тим, що пробіг між обслуговуванням електромобілів є більшим 
удвічі - 30 тис. км проти 15 тис. км у автомобілів з ДВ3 та гібридів, а трудомісткість технічного обслуговування електромобілів приблизно в 2,5 раза менша - 7 нормо-годин проти 15,7-19,8 нормогодин у автомобілів з ДВ3 при пробігу 105 тис. км. Також у 4-5 разів меншою є вартість витратних матеріалів, які використовуються при обслуговуванні через відсутність витратної номенклатури, пов’язаної з технічним обслуговуванням ДВЗ.

Висновки та перспективи подальшого дослідження. У статті запропоновано методику визначення питомої собівартості експлуатації транспортних засобів з різними типами силових установок, яка базується на нормативних документах, що діють на території України. Розраховано питому собівартість експлуатації найпопулярніших в Україні транспортних засобів з гібридною силовою установкою, ДВ3 та електромобілів. Показано, що доцільність використання різних типів автомобілів залежить від вартості самого автомобіля та вартостей таких різних компонентів експлуатації, як паливо та електроенергія, робоча сила, експлуатаційні матеріали, особливості податкового законодавства тощо, і має визначатися відповідно до умов кожної країни. У багатьох випадках сукупна вартість використання електромобілів $\epsilon$ більшою, ніж транспортних засобів з двигунами внутрішнього згоряння та гібридів. Якщо не враховувати вартість автомобіля і пов'язані 3 нею амортизаційні витрати, то експлуатація електромобілів є у 3-5 разів дешевшою за експлуатацію гібридів і в 5-8 разів дешевшою за експлуатацію автомобілів 3 ДВ3.

Таким чином, урахування амортизаційних відрахувань під час визначення питомої собівартості експлуатації транспортного засобу є важливою складовою, яку необхідно враховувати, особливо в умовах здійснення комерційної діяльності, оскільки це дасть можливість зробити більш виважений вибір рухомого складу для заданих умов експлуатації.

Розроблена методика дозволяє оцінити питому собівартість експлуатації транспортних засобів 3 різними типами силових установок і врахувати витрати на паливо та електроенергію для приведення в рух автомобіля, технічне обслуговування та поточний ремонт, мастильні та експлуатаційні матеріали, зношування та ремонт шин, інші прямі витрати, пов'язані з експлуатацією автомобіля та амортизаційні відрахування. Вона може бути рекомендована до використання на автотранспортних підприємствах, зокрема під час підбору рухомого складу для організації служби таксі. Також ця методика буде корисна приватним особам під час вибору автомобіля з огляду на економічну доцільність його використання.

Подальші дослідження варто спрямувати на розширення кількості факторів, які будуть більш детально враховувати умови експлуатації транспортного засобу. Також варто продовжувати роботу над розвитком бази даних результатів розрахунку з метою виявлення найбільш економічно доцільних транспортних засобів для різних умов експлуатації.

\section{Список використаної літератури:}

1. Количество зарегистрированных электромобилей и гибридов в Украине // HEvCars [Електронний ресурс]. Режим доступу : https://hevcars.com.ua/ev-sales-ukraine/.

2. В Украине количество электромобилей превысило 20 тыс. шт. // AutoConsulting [Електронний ресурс]. Режим доступу : http://www.autoconsulting.ua/article.php?sid=47126.

3. Электромобили в Украине станут популярнее евроблях только через 5 лет // Український бізнес ресурс [Електронний ресурс]. - Режим доступу : https://ubr.ua/market/auto/elektromobili-v-ukraine-stanut-populjarneeevrobljakh-tolko-cherez-5-let-3887476.

4. Как и где выгодней зарядить электромобиль в Украине - примеры расчетов // AxiomPlus [Електронний pecypc]. - Режим доступу : https://axiomplus.com.ua/news/kak-i-gde-vygodnej-zaryadit-elektromobil-v-ukraine/.

5. Стоимость содержания и ремонта электрокара Nissan LEAF в Украине // Elektrovesti.net [Електронний ресурс]. Режим доступу : https://elektrovesti.net/60052_stoimost-soderzhaniya-i-remonta-elektrokara-nissan-leaf-v-ukraine.

6. Опыт эксплуатации электромобиля Nissan Leaf S 2014 // HEvCars [Електронний ресурс]. - Режим доступу : https://hevcars.com.ua/reviews/opyit-ekspluatatsii-elektromobilya-nissan-leaf-s-2014-ot-igorya/.

7. Электрокары в украинских реалиях: стоимость и расходы // Сегодня [Електронний ресурс]. - Режим доступу : https://www.segodnya.ua/economics/avto/elektrokary-v-ukrainskih-realiyah-stoimost-i-rashody-702226.html.

8. Электромобиль - это не для меня // Хабр [Електронний ресурс]. - Режим доступу : https://m.habr.com/ru/post/459890/.

9. Насколько выгоднее использовать электромобили вместо авто с ДВС // Автоцентр [Електронний ресурс]. Режим доступу : https://www.autocentre.ua/opyt/tehnologii/naskolko-vygodnee-ispolzovat-elektromobili-vmestoavto-s-dvs-761041.html.

10. Стоимость эксплуатации электромобиля в сравнении с бензиновым авто // Автоцентр [Електронний pecypc]. - Режим доступу: https://www.autocentre.ua/avtopravo/avtobiznes/stoimost-ekspluatatsiielektromobilya-v-sravnenii-s-benzinovym-avto-398994.html.

11. Берегись электромобиля // Finance.ua [Електронний ресурс]. - Режим доступу : https://finance.ua/saving/beregis-elektromobilya.

12. Галущак Д.О. Аналіз розрахунку витрат на експлуатацію електромобіля та автомобіля 3 ДВ3 : матеріали XLVII науково-технічної конференції підрозділів ВНТУ, 14-23 березня 2018, Вінниця / Д.О. Галущак, Д.А. Шпирко [Електронний ресурс]. - Режим доступу : https://conferences.vntu.edu.ua/index.php/all-fmt/allfmt-2018/paper/view/4448. 
13. Положення (стандарт) бухгалтерського обліку 16 «Витрати» // Бухгалтер 911 [Електронний ресурс]. Режим доступу : https://buhgalter911.com/normativnaya-baza/instr-plan-rah/standart-buhgalterskogo/.

14. Методика розрахунку тарифів на послуги пасажирського автомобільного транспорту ; затверджено Наказом Міністерства транспорту та зв'язку України 17.11 .2009 р. № 1175, зареєстровано в Міністерстві юстиції України 27.11.2009 p. № 1146/17162 [Електронний ресурс]. - Режим доступу : https://zakon.rada.gov.ua/laws/show/z1146-09.

15. Порядок формування тарифів на послуги міського електричного транспорту (трамвай, тролейбус) ; затверджено Наказом Міністерства інфраструктури України 25.11.2013 р. № 940, зареєстровано в Міністерстві юстиції України 28.11.2013 р. № 2035/24567 [Електронний ресурс]. - Режим доступу : https://zakon.rada.gov.ua/laws/show/z2035-13\#n15.

16. Каталог нових автомобілів // InfoCar [Електронний ресурс]. - Режим доступу : https://www.infocar.ua/new-cars/.

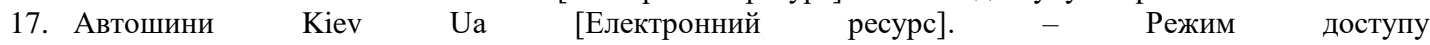
https://avtoshiny.kiev.ua/index.php?route=wheels/search/index\&category=1\&in_stock=1\&diametr=17\&width=215 \&height $=55 \&$ show $=$ table.

18. Некрасов В. Електромобіль і «гібрид»: що краще / В.Некрасов // Економічна правда [Електронний ресурс]. Режим доступу : https://www.epravda.com.ua/publications/2018/04/4/635652/.

19. Вартість технічного обслуговування // Nissan Україна [Електронний ресурс]. - Режим доступу : http://ua.nissan.ua/TO_calculator/.

20. Сіті Плаза [Електронний ресурс]. - Режим доступу : https://cityplaza.toyota.ua/.

21. Тойота Центр Київ «Автосаміт» [Електронний ресурc]. - Режим доступу : www.toyota.com.ua.

22. Tesla model S. Руководство по эксплуатации // Lingo Service [Електронний ресурс]. - Режим доступу : https://www.lingvoservice.ru/assets/files/model_s_rukovodstvo-po-ekspluatacii_5.9.pdf.

23. Техническое обслуживание Tesla [Електронний ресурс]. - Режим доступу : https://ion-cars.ru/service-tesla-model/.

24. Сервіс електромобілів. - ТОВ «Олмакс Груп» [Електронний ресурс]. - Режим доступу https://olmaks.ua/service/?gclid=EAIaIQobChMIkuerwbDY5wIVDMKyCh23uA70EAAYAiAAEgIjWfD_BwE.

\section{References:}

1. HEvCars, «Kolichestvo zaregistrirovannykh elektromobilei i gibridov v Ukraine», [Online], available at: https://hevcars.com.ua/ev-sales-ukraine/

2. AutoConsulting, «V Ukraine kolichestvo elektromobilei prevysilo 20 tys. sht.», [Online], available at: http://www.autoconsulting.ua/article.php?sid=47126

3. Ukrai'ns'kyj biznes resurs, «Elektromobili v Ukraine stanut populyarnee evroblyakh tol'ko cherez 5 let», [Online], available at: https://ubr.ua/market/auto/elektromobili-v-ukraine-stanut-populjarnee-evrobljakh-tolko-cherez-5-let-3887476

4. AxiomPlus, «Kak i gde vygodnei zaryadit' elektromobil' v Ukraine - primery raschetov», [Online], available at: https://axiomplus.com.ua/news/kak-i-gde-vygodnej-zaryadit-elektromobil-v-ukraine/

5. Elektrovesti.net, «Stoimost' soderzhaniya i remonta elektrokara Nissan LEAF v Ukraine», [Online], available at: https://elektrovesti.net/60052_stoimost-soderzhaniya-i-remonta-elektrokara-nissan-leaf-v-ukraine

6. HEvCars, «Opyt ekspluatatsii elektromobilya Nissan Leaf S 2014», [Online], available at: https://hevcars.com.ua/reviews/opyit-ekspluatatsii-elektromobilya-nissan-leaf-s-2014-ot-igorya/

7. Segodnya, «Elektrokary $v$ ukrainskikh realiyakh: stoimost' i raskhody», [Online], available at: https://www.segodnya.ua/economics/avto/elektrokary-v-ukrainskih-realiyah-stoimost-i-rashody-702226.html

8. Khabr, «Elektromobil' - eto ne dlya menya», [Online], available at: https://m.habr.com/ru/post/459890/

9. Avtotsentr, «Naskol'ko vygodnee ispol'zovat' elektromobili vmesto avto s DVS», [Online], available at: https://www.autocentre.ua/opyt/tehnologii/naskolko-vygodnee-ispolzovat-elektromobili-vmesto-avto-s-dvs-761041.html

10. Avtotsentr, «Stoimost' ekspluatatsii elektromobilya v sravnenii s benzinovym avto», [Online], available at: https://www.autocentre.ua/avtopravo/avtobiznes/stoimost-ekspluatatsii-elektromobilya-v-sravnenii-s-benzinovymavto-398994.html

11. Finance.ua, «Beregis' elektromobilya», [Online], available at: https://finance.ua/saving/beregis-elektromobilya

12. Galushhak, D.O. and Shpyrko, D.A., «Analiz rozrahunku vytrat na ekspluataciju elektromobilja ta avtomobilja $\mathrm{z}$ DVZ», materialy XLVII naukovo-tehnichnoi' konferencii' pidrozdiliv VNTU, 14-23 bereznja 2018, Vinnycja, [Online], available at: https://conferences.vntu.edu.ua/index.php/all-fmt/all-fmt-2018/paper/view/4448

13. Buhgalter 911, «Polozhennja (standart) buhgalters'kogo obliku 16 «Vytraty», [Online], available at: https://buhgalter911.com/normativnaya-baza/instr-plan-rah/standart-buhgalterskogo/

14. Ministerstvo transportu ta zv'jazku Ukrai'ny (2009), Metodyka rozrahunku taryfiv na poslugy pasazhyrs'kogo avtomobil'nogo transportu, Nakaz vid 17.11.2009 r. No. 1175, zarejestrovano v Ministerstvi justycii' Ukrai'ny 27.11.2009 r. No. 1146/17162, [Online], available at: https://zakon.rada.gov.ua/laws/show/z1146-09

15. Ministerstvo infrastruktury Ukrai'ny (2013), Porjadok formuvannja taryfiv na poslugy mis'kogo elektrychnogo transportu (tramvaj, trolejbus), Nakaz vid 25.11.2013 r. No. 940, zarejestrovano v Ministerstvi justycii' Ukrai'ny 28.11.2013 r. No. 2035/24567, [Online], available at: https://zakon.rada.gov.ua/laws/show/z2035-13\#n15

16. InfoCar, «Katalog novyh avtomobiliv», [Online], available at: https://www.infocar.ua/new-cars/

17. Avtoshyny Kiev Ua [Online], available https://avtoshiny.kiev.ua/index.php?route=wheels/search/index\&category=1\&in_stock=1\&diametr=17\&width=215 \&height=55\&show=table

18. Nekrasov, V., «Elektromobil' i «gibryd»: shho krashhe», Ekonomichna pravda, [Online], available at: https://www.epravda.com.ua/publications/2018/04/4/635652/

19. Nissan Ukrai'na, «Vartist' tehnichnogo obslugovuvannja», [Online], available at: http://ua.nissan.ua/TO_calculator/ 
20. Siti Plaza, [Online], available at: https://cityplaza.toyota.ua/

21. Tojota Centr Kyi'v «Avtosamit», [Online], available at: www.toyota.com.ua

22. Lingo Service, «Tesla model S. Rukovodstvo po ekspluatatsii», [Online], available at: https://www.lingvoservice.ru/assets/files/model_s_rukovodstvo-po-ekspluatacii_5.9.pdf

23. «Tekhnicheskoe obsluzhivanie Tesla», [Online], available at: https://ion-cars.ru/service-tesla-model/.

24. «Servis elektromobiliv», TOV «Olmaks Grup», [Online], available at: https://olmaks.ua/service/?gclid=EAIaIQobChMIkuerwbDY5wIVDMKyCh23uA70EAAYAiAAEgIjWfD_BwE

Андрусенко Сергій Іванович - кандидат технічних наук, професор, завідувач кафедри технічної експлуатації автомобілів та автосервісу Національного транспортного університету.

Наукові інтереси:

- підвищення економічної ефективності підприємств автосервісу.

https://orcid.org/0000-0002-9914-0200.

E-mail: sergeandrusenko@gmail.com.

Бугайчук Олександр Сергійович - кандидат технічних наук, доцент, доцент кафедри технічної експлуатації автомобілів та автосервісу Національного транспортного університету.

Наукові інтереси:

- управління якістю в автосервісі.

https://orcid.org/0000-0001-8646-6263.

E-mail: bug_os@ukr.net.

Лобода Андрій Вікторович - кандидат технічних наук, доцент, доцент кафедри технічної експлуатації автомобілів та автосервісу Національного транспортного університету.

Наукові інтереси:

- інформаційні технології на автомобільному транспорті.

https://orcid.org/0000-0002-6956-3288.

E-mail: aloboda@ukr.net.

Савостін-Косяк Данило Олександрович - кандидат технічних наук, доцент кафедри технічної експлуатації автомобілів та автосервісу Національного транспортного університету.

Наукові інтереси:

- витрата паливо-енергетичних ресурсів автомобільним транспортом.

https://orcid.org/0000-0002-8795-5939.

E-mail: daniel_s@ukr.net. 